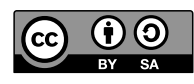

DOI: $10.4312 / \mathrm{mz} \cdot 56.2 .107-135$

UDK 781.7(497.4):681.84:78.072Marolt

\title{
France Marolt's Endeavours to Sound Document Folk Music
}

\author{
Drago Kunej
}

Research Centre of the Slovenian Academy of Sciences and Arts

\begin{abstract}
The paper presents France Marolt's endeavours spanning many years to acquire the recording devices that he planned to use for documenting folk music in the field, as well as for his research work and various forms of educational and cultural activities. The main focus is on researching the circumstances in which sound recordings on gramophone records were made in collaboration with Radio Ljubljana, and on the first sound collection of the Institute of Ethnomusicology ZRC SAZU, which consisted of these records. The records have a special documentary value and, combined with archival documents, convey Marolt's view of folk music.
\end{abstract}

Keywords: phonograph, gramophone records, Institute of Ethnomusicology, Radio Ljubljana, sound collection

\section{IZVLEČEK}

Članek predstavi dolgoletna prizadevanja Franceta Marolta za pridobitev snemalnih naprav, s katerimi je želel dokumentirati ljudsko glasbo na terenu in jih uporabljati pri raziskovalnem delu in različnih oblikah izobraževalnega in kulturnega delovanja. Pri tem se osredotoča na raziskavo okoliščin, $\mathrm{v}$ katerih so $\mathrm{v}$ sodelovanju $\mathrm{z}$ Radio Ljubljana nastali zvočni posnetki na gramofonskih ploščah, prvi zvočni zbirki Glasbenonarodopisnega inštituta ZRC SAZU; te plošče imajo posebno dokumentarno vrednost in skupaj z arhivsko dokumentacijo razkrivajo Maroltov pogled na ljudsko glasbo.

Ključne besede: fonograf, gramofonske plošče, Glasbenonarodopisni inštitut, Radio Ljubljana, zvočna zbirka

The article was written within the framework of the research programme Research on Slovenian Folk Culture in Folklore Studies and Ethnology, No. P6-0111, funded by the Slovenian Research Agency. 


\section{Introduction}

Throughout his career, France Marolt (1891-1951), whose work spanned various fields, disciplines and interests, was always strongly connected with Slovenian music and folk culture research. During the inter-war period, he was best known as the founder, conductor and choirmaster of the Academic Choir, i.e., the University of Ljubljana's student choir, which impressed the audience with its arrangements of Slovenian folk songs. At the time, Marolt's male-voice Academic Choir was considered one of the best choirs in Slovenia and was able to perform even more challenging musical works. ${ }^{1}$ Today, Marolt's name is synonymous with the folk dance ensemble that was founded by him in 1948 and is still active as one of the most renowned folk dance ensembles in Slovenia. The ensemble was later renamed the France Marolt Academic Folk Dance Ensemble in his honour.

Marolt's research work was crucial for the development of Slovenian ethnomusicology: he broke new ground in this field, laying the foundations for professional work and scholarly writing. ${ }^{2}$ The establishment of the Folklore Institute (the present-day Institute of Ethnomusicology ZRC SAZU) by the Music Society (Glasbena matica) in 1934 and the preparation of the institute's work plan and research guidelines make him the pioneer of institution-based folk music research in Slovenia. ${ }^{3}$

In his artistic and research work, Marolt soon became aware of the great importance of sound documentation of ethnomusicological material. When he founded the Folklore Institute, he was already planning to purchase a recording device. Later, he was constantly on the lookout for information on what was available in terms of the necessary technology and the most suitable device for his scientific work. As a lecturer at the Academy of Music, he emphasised the importance of using sound and film recording for ethnographic work and always strived to pass his practical knowledge on to the students. During the course of his collaboration with Radio Ljubljana, for which he prepared a series of radio lectures on Slovenian folk songs, his first sound recordings were made on gramophone records.

1 Cf. Andrej Misson, "Nekaj misli o slovenskem zborovskem skladanju med obema svetovnima vojnama," in Studia musicologica Labacensia: Nova glasba v "novi" Evropi med obema svetovnima vojnama, ed. Jernej Weiss (Koper: Založba Univerze na Primorskem, Festival Ljubljana, 2018), 248.

2 Cf. Matjaž Barbo, Slovenska muzikologija: Kratek prelet po zgodovini (Ljubljana: Znanstvena založba Filozofske fakultete, 2019), 72-73; Nataša Cigoj Krstulović, "Prizadevanja Glasbene matice za ohranitev in oživitev etničnega repertoarja ter ustanovitev Instituta za raziskovanje slovenske glasbene folklore leta 1934," Traditiones 43, no. 2 (2014): 230, https://doi.org/10.3986/ TradITIO2014430211.

3 On the centenary of France Marolt's birth, his ethnomusicological research work was presented and evaluated in: Zmaga Kumer, "France Marolt (1891-1951): Ob stoletnici rojstva slovenskega etnomuzikologa," Traditiones 20 (1991): 9-28, http://www.dlib. si/?URN=URN:NBN:SI:DOC-BDE0OZFP. 
Marolt's research and artistic work has been the subject of numerous discussions and reviews, and is relatively well known in professional circles. His activities related to sound recording documentation, however, have been researched to a lesser extent and thus not as much information is available about them. The aim of the paper is to present and shed light on Marolt's endeavours spanning many years to acquire the recording devices that he planned to use for recording and documenting folk music in the field, as well as for his research work, lectures and other forms of educational and cultural activities. The paper focuses on the circumstances in which sound recordings on gramophone records were made and on the first sound collection assembled by the Institute of Ethnomusicology ZRC SAZU, which consisted of these records. The records have an extraordinary documentary value as they were made with a special direct cut technology, not intended for mass production or to be sold, and have been preserved only in the form of the original single-copy sound carriers. For the most part, the study is based on various reports, documents and other archival sources, as well as the preserved gramophone records.

\section{From phonographs to gramophones and sound film}

France Marolt was planning to use sound recording in his field research and collection of folk music material as early as 1934, when the Institute for the Research of Slovenian Musical Folklore ${ }^{4}$ (soon after renamed the Folklore Institute of the Music Society and the present-day Institute of Ethnomusicology ZRC SAZU) was established. In the charter (agreement) describing the institute's organisation, aims and work ${ }^{5}$ - considered to be "the institute's founding document" - sound documentation of folk material was planned as an important part of the institute's field research. In order to achieve the institute's

4 On the initiative of Karel Mahkota, the administrative head and executive secretary of the Music Society, the following resolution was passed at the $6^{\text {th }}$ meeting of the Society's committee: "The Music Society is to establish [...] an independent department called the Institute for the Research of Slovenian Musical Folklore. This institute will be a joint institution of the Music Society and the Philharmonic Society, which, by agreement, will also cover all related expenses. The person in charge of the institute will be Mr Fran Marolt, appointed with a special contract." (NUK, Glasbena zbirka, arhiv Glasbene matice v Ljubljani 1872-1945, zapisniki odborovih sej od 14. 6. 1921 do 24.1.1936, zapisnik 6. odborove seje, 31. 8. 1934, 42).

5 Before the institute was established, Mahkota had several talks with Marolt to discuss its activities, which resulted in a charter describing the institute's organisation (the founders and the institute in relation to the Music Society as a special section of the Society), aims and work, as well as the duties and rights of the head of the institute. The charter lists the most important responsibilities of the institute itself and its head. Marolt was supposed to start working and take up the post of the institute's head on 15 October 1934, which is considered the start of the institute's work (cf. Krstulović, "Prizadevanja Glasbene matice," 225).

6 Zmaga Kumer, Ob 50-letnici ustanovitve Folklornega inštituta (Ljubljana: ZRC SAZU, Inštitut za slovensko narodopisje, 1984), 1; Kumer, "Ustanovitev in razvoj do jeseni leta 1999," in 65 let Glasbenonarodopisnega inštituta ZRC SAZU: 1934-1999, ed. Marko Terseglav (Ljubljana: Založba ZRC, ZRC SAZU, 2000), 11. 
main objective, which was "to compile the most comprehensive collection of Slovenian musical folklore, i.e., to collect all of the existing song-related materials that were available in written form [...] and continuously add new ones", the charter listed the institute's work tasks in detail, in particular "documenting and phonographing folklore material". ${ }^{7}$ Zmaga Kumer, later one of the institute's researchers and a colleague of Marolt, believed that "the author of the agreement was undoubtedly Marolt himself, as revealed by the text's content and writing style". In claiming this, she referred mainly to the ambitious ethnomusicological work and research-related plans and called Marolt "the institute's conceptual founder". ${ }^{8}$

Marolt based the work plan of the newly established institute on his vast knowledge of the state of "Slovenian musical ethnography", as revealed in a letter dated 14 December $1935,{ }^{9}$ sent by Marolt to the Croatian researcher Josip Široki, ${ }^{10}$ in which he mentions sound recordings, among other things. This particular letter is a lengthy reply to a letter Široki had sent to Marolt on 24 October 1935, ${ }^{11}$ asking him for information on Slovenian institutions, collections, bibliography and researchers related to folk music research. Široki specifically mentions a possible "collection of phonograms [...], preferably a number of gramophone records, and recorded and written melodies", as well as a collection of "sound films with melodies (songs, dances) for scientific purposes". In the first few pages of his reply, Marolt presents a "brief history of Slovenian ethnographic work to date", also mentioning the first sound recording documentation of Slovenian researchers and the need to continue

7 NUK, Glasbena zbirka, arhiv Glasbene matice v Ljubljani 1872-1945, zapisniki odborovih sej od 14. 6. 1921 do 24.1.1936, zapisnik 7. odborove seje, 14. 9. 1934, 50-51.

8 Kumer, "Ustanovitev in razvoj do jeseni leta 1999," 12.

9 ZRC SAZU, Glasbenonarodopisni inštitut, arhivsko gradivo, znanstvena korespondenca, Zn. dps. 18/10, 1935.

10 Dr Josip Široki (1882-1963) was a Croatian folklore researcher and collector (musical instruments, objects of daily life and art, drawings of traditional bridges and mills, etc.). He studied philosophy and music in Vienna, combining this with studies in philology (Slavic and German) and pedagogy. He completed his studies in Vienna with a doctorate in musicology and philosophy, and is considered the first Croatian doctor of musicology. Although he was active in many scientific disciplines and authored a number of works of great value for the knowledge of Croatian cultural heritage, he is not particularly well known among researchers. His best-preserved work is the sound collection in the Phonogrammarchiv of the Austrian Academy of Sciences in Vienna, where he made more than 120 recordings before World War II. Although he did not use conventional research methods - he made recordings of his own performances (singing, playing musical instruments) - the recordings are valuable documents that connect the folk material with Široki's wealth of musical and linguistic knowledge in a special way. He was considered an eccentric and bohemian person. At the end of his life, he was lonely and he died almost forgotten (cf. Svanibor Pettan, “Josip Široki - prvi hrvatski doktor muzikologije," Od-Do 4, no. 35 (1982): 4-6; Vera Tiefenthaler, "Josip Široki: singer and transcriber at the same time: An analysis of his aims, methods, and findings," Traditiones 34, no. 1 (2005): 91-99, https://doi.org/10.3986/Traditio2005340107).

11 ZRC SAZU, Glasbenonarodopisni inštitut, arhivsko gradivo, znanstvena korespondenca, Zn. dps. 17/1(2), 1935. 
such documentation when collecting folk songs in the field. Years before that, Marolt had in fact already helped Stanko Vurnik, curator at the Ethnographic Museum in Ljubljana, by organising the song collection of the Committee for the Collection of Slovenian Folk Songs (Odbor za nabiranje slovenskih narodnih pesmi, OSNP), which had been taken over by the museum from the $\mathrm{Mu}-$ sic Society in 1927. ${ }^{12}$ According to Marolt, even back then it turned out that "in some folklore districts", which were "researched either insufficiently or not at all", it was necessary to continue documenting folk songs and to "add new materials to the previously collected ones". In his letter to Josip Široki, Marolt wrote: "for this reason I pointed out to Dr Vurnik that we had to get the defective phonograph from the Music Society and have it repaired, and that it was time to start the long-overdue collection of materials. However, thanks to the director of the Ethnographic Museum, Dr Niko Zupanič, this never happened [...]". Here Marolt is referring to the phonograph used by Juro Adlešič in Bela Krajina in 1914 to make sound recordings at the request of the OSNP Committee. ${ }^{13} \mathrm{He}$ also mentions that " 18 songs on cylinders", phonographed by Juro Adlešič, were in the possession of the Ethnographic Museum in Ljubljana. He points out that they were "not yet able to afford sound film recordings of tunes and dances for scientific purposes", although they already planned to do so for the "staged reconstruction of three rituals from Gailtal in the original form" and adds that they "were unable to reproduce them in sound film as this was too costly".

France Marolt's plan was not only to use sound documentation in his future research work, he wanted to start making recordings as soon as the institute commenced its work. Thus, the oldest document in the archival correspondence of the Institute of Ethnomusicology ZRC SAZU is a letter sent to the Phonogramm-Archiv in Berlin regarding the purchase of a recording device: a phonograph and cylinders. ${ }^{14}$ The letter is signed by Marolt and dated 4 September 1934, that is, before the institute officially commenced its work. The letter also includes an order for recording equipment (a phonograph accompanied by 100 recording cylinders). The ordered equipment was supposed to be delivered as soon as possible and payment would be made immediately after the invoice had been issued. The letter left the choice of the "brand" to the supplier, adding that they should choose the "best possible" device, which must be intended for "scientific use". A request for detailed instructions for use and

12 Drago Kunej, "Fonografski posnetki slovenskih ljudskih pesmi iz Bele krajine v SEM: Rezultat lastnih snemanj ali pridobljeno gradivo OSNP?” Etnolog 19 (2009): 225-235, http://www.dlib. si/?URN=URN:NBN:SI:DOC-4XVJMEM1.

13 See also Drago Kunej, "We have plenty of words written down, we need melodies!: The purchase of the first recording device for ethnomusicological research in Slovenia," Traditiones 34, no. 1 (2005): 125-140, https://doi.org/10.3986/Traditio2005340110.

14 ZRC SAZU, Glasbenonarodopisni inštitut, arhivsko gradivo, znanstvena korespondenca, Zn. dps. 1/1(1), 1934. 
a list of brochures was also included. Marolt probably based this on the past experience of Slovenian researchers with recording by means of the Edison phonograph and familiarity with the OSNP Committee's recorded material, which was at the time kept at the Ethnographic Museum in Ljubljana. ${ }^{15}$

Soon after, Marolt received a reply to his letter from Marius Schneider, the head of the Phonogramm-Archiv in Berlin. ${ }^{16}$ Before the actual delivery, Schneider wanted to verify that they really wanted the sort of phonograph specified in the letter. By way of explanation, he pointed out that the kind of phonographs Marolt wanted to order were technically outdated. Due to the hand-cranked design, the only place they were still used was in places with no electricity. Where electricity was available, the Phonogramm-Archiv used modern devices that recorded on cylinders or discs, so-called parlographs manufactured by Lindström and Telefunken. Schneider also added the prices, with modern devices being approximately ten times more expensive than simple phonographs. In conclusion, he noted that he was happy to help with the purchase of the recording device, but added that they were welcome to contact the aforementioned manufacturers directly and provided the necessary contact details.

The institute's archival documentation contains no further correspondence with the Berlin Phonogramm-Archiv. Contrary to the original plan, Marolt evidently decided against buying a simple Edison phonograph. It is possible that Schneider's explanation prompted him to consider a more state-of-theart and high-quality recording device. Archival documents reveal that Marolt wanted to get more information on the advancements in recording technology for research work so that he could make a more informed purchase decision.

In 1934, Marolt was presented with a comprehensive picture of recording technology in France by Drago Šijanec, ${ }^{17}$ who was studying in Paris at the time. It appears that soon after starting work at the institute, Marolt asked

15 For more see Kunej, "Fonografski posnetki."

16 ZRC SAZU, Glasbenonarodopisni inštitut, arhivsko gradivo, znanstvena korespondenca, Zn. dps. 2/1(1), 1934

17 Drago Mario Šijanec (1907-1986) was a Slovenian conductor, violist and composer. He studied composition, conducting and viola in Prague, where he also received education in music recording. Between 1932 and 1935, he continued his studies in Paris, as he had won a three-year scholarship from the Paris Phonetic Institute. He researched and recorded the folk dance music of the Lusatians for the institute. During the period 1935-1945, he was the conductor of the Ljubljana Radio Orchestra. After World War II, the Slovenian authorities accused him of violating cultural silence, so he lost his job at Radio Ljubljana and was also prevented from doing any other music-related work. Consequently, he moved to Italy, where he served as a violist in the Turin Opera Orchestra. In 1947, he decided to leave for Argentina, where he built a successful career as a conductor and conductor-teacher. Cf. Dragotin Cvetko, "Šijanec, Drago Mario (1907-1986)," in Slovenska biografija (Slovenska akademija znanosti in umetnosti, Znanstvenoraziskovalni center SAZU, 2013), accessed 24 June 2020, http://www.slovenska-biografija.si/ oseba/sbi648279/\#slovenski-biografski-leksikon. 
Šijanec for help with the purchase of a recording device, probably also mentioning the specific recording device he was planning to buy and asking Šijanec for his opinion. However, this document has not been preserved and the only hint as to what was written in Marolt's request is a preserved letter from Drago Šijanec dated 18 December $1934 .{ }^{18}$ In this letter, Sijanec apologises to Marolt for taking so long to reply, explaining that he "did not want to send a hasty reply, so he could find out as much as possible first". In the introduction, he writes that he has consulted "several of his sources about the phonograph", adding that even in Paris they were familiar with the "best German device (Neumann)", which he believes to be the one Marolt is planning to buy. After a brief description of this device, he verifies Marolt's intentions: "Is this the one you were thinking of buying?". This suggests that Marolt had written to Sijanec with a rather clear intention of purchasing a specific recording device.

Later in the same letter, Šijanec provides specific information on recording devices and the experience of their use, which he received from the director of the Sorbonne Phonetic Institute. The latter was thoroughly familiar with the Neumann device in question, and with the state of recording technology around the world in general, as a result of which Šijanec "valued his opinion". According to him, small recording devices were quite widespread and were constantly improving, but they were intended primarily for amateurs: "They are not sensitive enough for scientific work", as "the reproductions are not clear and the records can be used only 7-10 times" (i.e., played back). The Phonetic Institute had "two large Pathé devices, which occupied the whole room", and in terms of "portable devices, the institute used a device invented by Dr Brettmann, who was the leading authority in this field at the time". His device "turned out to be much better than the best German (Neumann) one, [...] which was outdated and could only produce wax discs". Brettmann's latest device was the size of a gramophone ("Kofferformat"), was "electrically powered and had a microphone". Moreover, "it could produce aluminium or wax discs, and responded to the finest voices". In his letter, Šijanec also provides the prices of individual devices, adding that "it would be difficult to get one that was both good and inexpensive". Almost all of the devices he listed were sound-recording devices that used discs as sound carriers, i.e., different versions of gramophones, although he also uses the term phonograph to refer to them whenever he wants to emphasise that they could also be used for recording as opposed to just playback.

A large amount of information about the research guidelines in the early period of the institute's work and the intention to use recording technology for material documentation is revealed by the minutes of the institute's first few

18 ZRC SAZU, Glasbenonarodopisni inštitut, arhivsko gradivo, znanstvena korespondenca, Zn. dps. 3/2(1), 1934. 
meetings. At the second meeting on 22 December 1934, the topic of sound recording was already on the agenda. This is confirmed by a short handwritten document entitled Meeting Agenda dated 18 December 1934, ${ }^{19}$ in which agenda items Nos 4 and 6 are "the phonograph" and "phonographic material", respectively. The minutes of this particular meeting ${ }^{20}$ reveal that the Minority Institute intended to buy a recording device, which would also be at the Folklore Institute's disposal for its ethnographic work. For the purposes of future recording needs, the Folklore Institute decided to buy fifty discs. It was also decided that "as soon as the device was available" Marolt would travel to Klagenfurt, where he would record a 100-year-old woman and her daughter, who "knew some of the most interesting Carinthian folk songs". However, it appears that the institute never managed to borrow the recording device and the trip to Klagenfurt never eventuated, as no recordings or trip reports have been found. Nor is there any information about the purchase of discs or any recordings made on them.

Marolt's original intention to purchase a simple Edison phonograph to make recordings on wax cylinders thus soon changed. He instead decided to purchase a more modern sound-recording device that used gramophone records (discs). Ever since the institute was established, he also had an ambitious plan to buy a device for recording sound film, as he wanted to ensure the "restoration of Slovenian musical-folkloristic assets with the help of sound film". ${ }^{21}$ This is evidenced, among other things, by some archival documents with offers of specific models of devices, as well as by the fact that the need to purchase such a device was expressed in the institute's various work plans. ${ }^{22}$ However, the Music Society committee soon informed Marolt that the purchase of a device for recording sound film would not be possible, as this was not financially viable. ${ }^{23}$

Despite clear intentions and the wish to purchase a recording device for research work (it is clear from some of the letters that the institute was very close to actually ordering one), it was not until much later that the institute obtained its own equipment. This was due in part to the institute's difficult financial situation and the "inadequacy" of cheaper recording devices, as well as the very limited research work undertaken during World War II. Another likely reason was the beginning of Marolt's collaboration with the Ljubljana Radio

19 ZRC SAZU, Glasbenonarodopisni inštitut, arhivsko gradivo, strokovna in uradna korespondenca, Urd. dps. 8/7, 1934.

20 NUK, Glasbena zbirka, Glasbena matica Ljubljana, mapa Glasbena matica/Folklorni inštitut, zapisnik II. seje odseka instituta za raziskavanje glasbenega folklora, 22.12.1934.

21 Kumer, “Ustanovitev in razvoj do jeseni leta 1999," 12.

22 ZRC SAZU, Glasbenonarodopisni inštitut, arhivsko gradivo, strokovna in uradna korespondenca, Urd. dps. 10/1, 1935; ZRC SAZU, Glasbenonarodopisni inštitut, arhivsko gradivo, strokovna in uradna korespondenca, Urd. dps. 12/a, b, 1935.

23 ZRC SAZU, Glasbenonarodopisni inštitut, arhivsko gradivo, strokovna in uradna korespondenca, Urd. dps. 13/1, 1935. 
Broadcasting Station, which owned its own recording devices. Marolt was able to make his first folk music recordings by using this equipment.

\section{Recording as part of lectures and collaboration with the Ljubljana Radio Broadcasting Station}

Research work - which is what prompted Marolt to attempt to acquire a recording device and compile a collection of Slovenian folk music heritage during the first few years of the institute's work, in addition to organising and cataloguing the collected material, collecting literature on folk music heritage and preparing critical studies - was a large part of Marolt's work, but it was not his only focus. He also devoted a lot of his time to various presentations and lectures, by means of which he tried to arouse more widespread interest in folk music heritage. His aim was to attract collaborators for "folkloristic work", "to make people - especially teachers, the clergy and students - interested in this sort of work", ${ }^{24}$ and, similarly to a collection campaign organised by the OSNP Committee, to revive the collecting of materials among people. ${ }^{25}$

In his lectures, Marolt often used slide presentations with photographic examples as well as musical demonstrations with instrumental and vocal arrangements performed on the piano and by a small group of singers. He repeatedly mentioned that his lectures aroused a great deal of interest, but they were also connected to his beginnings in sound recording and documentation.

The first sound recordings that Marolt participated in were made during lectures at the Ljubljana Radio Broadcasting Station. He had been invited to prepare the first radio lecture as early as January 1936: on a postal card dated 10 January 1936, Marolt was invited to prepare a lecture "according to what had been discussed". The lecture was scheduled to be aired on Monday, 3 February 1936 "as part of the cultural chronicle at 18:40 and would last 20 minutes". ${ }^{26}$ On the next postal card, dated 28 January 1936, Marolt was once

24 NUK, Glasbena zbirka, Glasbena matica Ljubljana, mapa Glasbena matica/Folklorni inštitut, Glasbena Matica v Ljubljani predlaga Akademiji znanosti in umetnosti v Ljubljani, da prevzame Folklorni institut Glasbene Matice, 22.5.1939.

25 Marolt gave various public "ethnographic" lectures: in the winter semester of 1935/36, he lectured for conservatory students, as well as in the Gailtal Valley/Ziljska dolina (1935) and in the Bela Krajina region (1936), with the aim of arousing the interest of local people in folk heritage. He also made teachers aware of the importance of folk songs for "national education" and inspired them to collect songs (Domžale 1937, Ljubljana 1940). He prepared a series of radio lectures for Radio Ljubljana (1936-1937) and lectured to the general public on "modern views and newer principles of ethnographic science", as well as on the music and characteristics of Slovenian folk dances (1937). Moreover, he planned a two-week ethnomusicology course (1938) (cf. NUK, Glasbena zbirka, Glasbena matica Ljubljana, mapa Glasbena matica/Folklorni inštitut, Glasbena Matica v Ljubljani predlaga Akademiji znanosti in umetnosti v Ljubljani, da prevzame Folklorni institut Glasbene Matice, 22. 5. 1939).

26 ZRC SAZU, Glasbenonarodopisni inštitut, arhivsko gradivo, znanstvena korespondenca, Zn. dps. 20/1, 1936 . 
again informed that his lecture "On Our Musical Folklore" was scheduled for Monday, 3 February 1936, at 18:40. France Koblar, ${ }^{27}$ the then head of the Radio's administration and programme, who signed the card, added a handwritten note, emphasising that "the matter was most urgent" and that Marolt "should reply, so they would know whether or not he was going to do it". ${ }^{28}$

Marolt probably did not give the lecture, as there is no mention of it in the 1935/1936 Work Report. ${ }^{29}$ Moreover, he pointed out in the 1936/1937 Work Plan section that during this period, Radio Ljubljana wanted to air a series of 12 to 16 ethnographic lectures, for which he would need "a small chamber choir". The fact that the lectures actually started in the autumn of 1936 is further confirmed by a letter dated 9 October 1936, ${ }^{30}$ in which Radio Ljubljana informed Marolt that the first lecture "on Slovenian folk songs" would be aired on "Monday, 19 October 1936, at 18:40 and would last until 19:00". The lectures were scheduled for every other Monday at the same time.

Marolt did give a series of lectures in the autumn and winter of 1936, as evidenced by the 1936 Work Report, ${ }^{31}$ in which he mentioned that he had "prepared and edited cultural and political lectures entitled 'Slovenian Folk Songs' for Radio Ljubljana”. By February 1937, he had presented ten lectures from this series, featuring an ad hoc Music Society octet, a Music Society youth choir, and the Sloga orchestra. According to Marolt's report, the lectures lasted half an hour each and were broadcast every other Monday between 18 October 1936 and 22 February 1937. In terms of the content, the lectures covered various topics, such as "tree worship rituals", "the remnants of these rituals among Slovenians" and "related customs (Childermas rituals, Christian Easter customs)". ${ }^{32}$

27 France Koblar (1889-1975) was a Slovenian literary historian, theatre critic, editor and translator, as well as a longstanding grammar school teacher (1919-1946). Between 1929 and 1932, he worked at Radio Ljubljana as a drama and culture editor, and between 1935 and 1941 he was the head of the administration and the radio programme. During the period 1937-1945, he was the president of the Slovene Writers' Association; between 1945 and his retirement in 1970, he lectured as a full professor of the history of drama at the newly established Academy of Performing Arts; and during the period 1952-1956, he was also the university's chancellor. In 1964, he was elected a full member of the Slovenian Academy of Sciences and Arts (SAZU). From 1972 to 1975, he was also the director of the Institute of Slovenian Ethnology ZRC SAZU. He was a committee member, vice-president and president of the Slovenian Society (Slovenska matica) (1966-1975) (cf. Wikipedia, s. v. "France Koblar," last modified 19 January 2019, accessed 19 June 2020, https://sl.wikipedia.org/wiki/France_Koblar).

28 ZRC SAZU, Glasbenonarodopisni inštitut, arhivsko gradivo, znanstvena korespondenca, Zn. dps. 22/1, 1936

29 ZRC SAZU, Glasbenonarodopisni inštitut, arhivsko gradivo, strokovna in uradna korespondenca, Urd. dps. 42/4, 1936.

30 ZRC SAZU, Glasbenonarodopisni inštitut, arhivsko gradivo, strokovna in uradna korespondenca, Urd. dps. 45/1, 1936

31 ZRC SAZU, Glasbenonarodopisni inštitut, arhivsko gradivo, strokovna in uradna korespondenca, Urd. dps. 55/2, 1937.

Ibid. 
In the spring of 1937, Marolt continued with his lectures, and also planned to give a few more during the summer: "every other Monday as scheduled". At first, Radio Ljubljana confirmed this, ${ }^{33}$ but in a letter dated 2 July $1937,{ }^{34}$ they informed him that the summer was not a particularly suitable time for a series of such lectures, so they would suspend them briefly, before continuing in the "winter season".

The lectures were not, however, resumed in the autumn of 1937. Marolt reported that he had suspended them due to his heavy workload, and also because he had not yet collected and prepared the material for future lectures. In a report dated 21 January $1938,{ }^{35}$ he noted that his lectures had by then covered all of the topics apart from "Midsummer's Day customs and songs", and that he would have "the scientific material on Midsummer's Day and wedding customs prepared" by the autumn of 1938 and could thus "continue with his radio lectures". However, no further lectures eventuated at this time either, as there is no mention of any lectures in the subsequent annual reports. The fact that he gave no more lectures is further confirmed by a letter dated 22 May $1939,{ }^{36}$ in which Marolt describes in detail the work of the Folklore Institute. ${ }^{37}$ In this letter, he also mentions that he has given a total of 15 lectures "on the planned topics regarding our folk songs" at the invitation of Radio Ljubljana. The lectures were part of the Cultural Chronicle and were broadcast "between 3 February $1935^{38}$ and 24 May 1937". He points out once again that he used musical examples performed on the piano for "analytical" illustrations, and that the "Sloga orchestra, a small mixed choir, a Music Society youth choir and an Academic Choir octet was also part of the lectures".

Some performances of the folk songs featured in Marolt's radio lectures were recorded by Radio Ljubljana on gramophone records. It was agreed that the institute would receive a copy of each record. Recording probably commenced in November 1936, shortly after the start of the radio lectures. A preserved letter dated 24 November 1936, ${ }^{39}$ sent to Marolt by the head

33 ZRC SAZU, Glasbenonarodopisni inštitut, arhivsko gradivo, znanstvena korespondenca, Zn. dps. 60/1, 1937.

34 ZRC SAZU, Glasbenonarodopisni inštitut, arhivsko gradivo, znanstvena korespondenca, Zn. dps. 66/1, 1937.

35 ZRC SAZU, Glasbenonarodopisni inštitut, arhivsko gradivo, strokovna in uradna korespondenca, Urd. dps. 72/4, 1938.

36 NUK, mapa Glasbena matica/Folklorni inštitut, 22. 5. 1939.

37 Due to the Folklore Institute's staffing, financial and spatial requirements, in May 1939, Music Society proposed that the institute be taken over by the newly established Academy of Sciences and Arts. Marolt was asked to prepare a detailed report on the institute's previous work and plans for the future.

38 This is most likely a mistake, as according to other archival documents, the first radio lecture had originally been planned for 3 February 1936, but was in actual fact probably aired on 19 October 1936.

39 ZRC SAZU, Glasbenonarodopisni inštitut, arhivsko gradivo, znanstvena korespondenca, Zn. dps. 48/1, 1936 . 
of the Radio Ljubljana programme, France Koblar, informs Marolt that the Radio received a letter from the Music Society on 18 November 1936 with a request for a copy of the records with the songs broadcast as part of Marolt's radio lecture on 16 November 1936. Koblar also points out that an agreement has been reached between the Music Society and the lecturer, "that folk songs would be recorded once, provided that the Folklore Institute received a record with each recording for its archives". He asks Marolt for his opinion and consent regarding the copies, suggesting that in future, records should be recorded in advance. Therefore, Marolt was to select some musical examples for the lectures, so they could record several examples during a single recording session. ${ }^{40}$

Marolt agreed to the copies and noted in the institute's work plan (dated 21 December 1936$)^{41}$ for the following year that his radio lectures "had already produced many positive results". Among other things, listeners had sent him a number of old songbooks with folk songs, and various researchers had contacted Radio Ljubljana regarding folk songs. ${ }^{42}$ The recordings on gramophone records also attracted a lot of interest and proved of considerable value to other researchers, as well. For instance, in February 1937, ${ }^{43}$ Božo Škerlj ${ }^{44}$ asked Marolt for permission to make copies of records with the recordings of songs and dances from Bela Krajina that had been part of Marolt's radio lectures. Škerlj asked Marolt to make the copies as a favour, as he was preparing a lecture and needed the recordings in question. According to him, Marolt's recorded examples were certainly the most representative of all existing recordings.

40 The recording sessions announced in advance, for which Marolt proposed songs and performers, are further confirmed by a letter dated 23 April 1937. As the choirmaster of the Academic Choir, Marolt was informed that the management of Radio Ljubljana had not agreed to the choir's fee for "recording the Carinthian Rej dance and that the recording would thus not take place" (ZRC SAZU, Glasbenonarodopisni inštitut, arhivsko gradivo, znanstvena korespondenca, Zn. dps. 61/1, 1937).

41 ZRC SAZU, Glasbenonarodopisni inštitut, arhivsko gradivo, znanstvena korespondenca, Zn. dps. 50/5, 1936 .

42 ZRC SAZU, Glasbenonarodopisni inštitut, arhivsko gradivo, znanstvena korespondenca, Zn. dps. 55/1, 1937 .

43 ZRC SAZU, Glasbenonarodopisni inštitut, arhivsko gradivo, znanstvena korespondenca, Zn. dps. 59/1, 1937.

44 Božo Škerlj (1904-1961) was an anthropologist who obtained his doctorate in Prague, continued his further education abroad, and lectured on physical anthropology at the University of Ljubljana. He was the leading Slovenian anthropologist and one of the world's most prominent figures in this field, as confirmed by his extensive bibliography. He contributed greatly to the advancement of Slovenian anthropology. He established the Department of Anthropology and connected anthropology with a number of other related scientific disciplines that are concerned with the study of human beings (cf. Zmagoslav Bufon, "Škerlj, Božo (19041961)," Slovenska biografja (Slovenska akademija znanosti in umetnosti, Znanstvenoraziskovalni center SAZU, 2013), accessed 22 June 2020, http://www.slovenska-biografija.si/oseba/ sbi654107/\#slovenski-biografski-leksikon). 
Marolt also reported that in 1936, one of his Radio Ljubljana associates, "Prof. Osana, Electrical Engineer, ${ }^{45}$ managed to construct high-quality and durable electrically reinforced phonograph discs, which were the only documentary material for critical research". ${ }^{46}$ In collaboration with Prof. Osana, Marolt planned to "document all of the available folkloristic musicological material". The institute was to receive a copy of the recordings made as part of Marolt's radio lectures for free, while other recordings were available "for 50 to 60 dinars per double-sided record". ${ }^{47}$

Marolt also gave practical demonstrations of working with recording devices and sound recordings as part of his ethnomusicological course, with the aim of training future collaborators for "collection campaigns of Slovenian musical folklore". A one-week ethnomusicological course under the auspices of the Folklore Institute was organised "for musically qualified teachers" between 1 and 6 July 1940..$^{48}$ The course included lectures by France Marolt and various guest lecturers in the morning, while in the afternoon the focus was "on nothing but practical work (linguistic experiments, practical notation of live cases while recording on electro-phonograph discs)". ${ }^{49}$ Marolt reported that "the first time he recorded by means of an electro-phonograph, he used a device belonging to the Academy of Music, a Telefunken-Tonfolien-Schneid-und Wiedergabegerät ELA A 107/1, which proved to be quite good". ${ }^{50}$ Although it was not possible to electrically reinforce the recordings, it was possible to make "high-quality copies equivalent to the original". In a letter sent to Božidar Sirola, ${ }^{51}$ in which Marolt reports about the course, he also lists the price of the

45 Marij Osana (1880-1958), a Slovenian electrical engineer, was the pioneer of education and research work in the field of telecommunications in Slovenia. He is considered the "father of radio in Slovenia", and was also the first technical head of Radio Ljubljana. During the period 1922-1932, he introduced and organised a radiotelegraph and radiotelephone network for the stations in Belgrade, Ljubljana, Skopje and Zagreb. From 1923 to 1957, he lectured at the Technical Faculty in Ljubljana and was also repeatedly elected its dean. During the period 1928-1930, he was in charge of the establishment of a high-frequency laboratory at the University of Ljubljana's Electrical Engineering Institute. In 1932, he planned and managed the construction of a broadcast transmitter for the Ljubljana radio station in Domžale with a transmitting power of 5 kW (cf. Wikipedia, s. v. "Marij Osana," last modified 9 June 2017, accessed 22 June 2020, https:// sl.wikipedia.org/wiki/Marij_Osana).

46 ZRC SAZU, Glasbenonarodopisni inštitut, Zn. dps. 50/5, 1936.

47 Ibid.

48 Originally, the first such two-week ethnomusicological course was to take place in March 1938 in Ljubljana with the aim of training numerous organists, choirmasters and other people involved in folk music collection. Despite extensive preparations, however, the course was cancelled, as it did not receive the necessary financial support (NUK, mapa Glasbena matica/Folklorni inštitut, 22.5. 1939).

49 ZRC SAZU, Glasbenonarodopisni inštitut, arhivsko gradivo, znanstvena korespondenca, Zn. dps. 104/1, 1940.

50 Ibid.

51 Božidar Širola (1889-1956) was a Croatian composer, musicologist and ethnomusicologist. He graduated in mathematics and physics in Zagreb and then started teaching at a grammar school. 
equipment and the records, adding that "leaflets with plenty of information could be delivered [from] the Ljubljana radio". It appears that in addition to the device belonging to the Academy of Music, which Marolt borrowed for the course, another such device was owned by Radio Ljubljana. No recordings from the course have been preserved, and in later documents Marolt never mentioned this device being used for any recordings of folk music.

All of the above suggests that the recording of gramophone records as part of Marolt's Radio Ljubljana lectures and the agreement to make copies of records for the Folklore Institute laid the foundations for a collection of gramophone records: the institute's first sound collection, which was created at a later time.

\section{The Gramophone Record Collection of the Folklore Institute}

As early as 1936 and 1937, it was agreed after some discussion that copies were to be made of the sound recordings from the gramophone records used by Marolt for his Radio Ljubljana lectures, and that the Folklore Institute would get copies of the records. It nevertheless took several more years for the institute to actually acquire its own collection of gramophone records.

Thus, there is no mention of the gramophone record collection in any of the Folklore Institute's Work Reports for the business years 1936/37, ${ }^{52} 1937 / 38,{ }^{53}$ or 1938/39..${ }^{54}$ Nor is the collection mentioned in an in-depth report about the institute's work over a five-year period that was prepared by Marolt on 22 May $1939^{55}$ as a proposal to the Academy of Sciences and Arts in Ljubljana to take over the institute, although these reports did detail the collected material. ${ }^{56} \mathrm{In}$ a report dated 29 December 1939, ${ }^{57}$ in which Marolt noted that he and his

At the same time, he was tutored by composer Ivan Zajc, before continuing his studies at the University of Vienna, where he obtained a musicology doctorate in 1921. In Zagreb, he worked as a high school teacher, curator and director of the Ethnographic Museum, as well as serving as dean of the Academy of Music. He is best known as a composer of various musical works, a musicologist and an ethnomusicologist who authored numerous papers on Croatian folk music (cf. "Širola, Božidar," in Hrvatska enciklopedija, Leksikografski zavod Miroslav Krleža, 2020, accessed 24 June 2020, http://www.enciklopedija.hr/Natuknica.aspx?ID=59596).

52 ZRC SAZU, Glasbenonarodopisni inštitut, Urd. dps. 72/4, 1938.

53 ZRC SAZU, Glasbenonarodopisni inštitut, arhivsko gradivo, strokovna in uradna korespondenca, Urd. dps. 81/2, 1939 .

54 ZRC SAZU, Glasbenonarodopisni inštitut, arhivsko gradivo, strokovna in uradna korespondenca, Urd. dps. 111/1, 1940.

55 NUK, mapa Glasbena matica/Folklorni inštitut, 22. 5.1939.

56 In the conclusion of the report from 1939, specifically in the section entitled "Conditions for Successful Work of the Institute", it is emphasised that the Institute needed an extraordinary grant for the purchase of "necessary equipment/a phonograph and a camera". In relation to this, Marolt believed that "recordings on Radio Ljubljana's electrically reinforced phonograph discs" would be a better option. In the submitted budget, he specified the cost of "a phonograph and camera with accessories" and "a phonograph cylinders/discs".

57 ZRC SAZU, Glasbenonarodopisni inštitut, arhivsko gradivo, strokovna in uradna korespondenca, Urd. dps. 112/1, 1939. 
assistant had "compiled a comprehensive inventory of the Folklore Institute", he similarly made no mention of any gramophone records or sound materials of any other kind. Nor were any gramophone records or sound materials mentioned by Croatian ethnomusicologist and director of the Ethnographic $\mathrm{Mu}-$ seum in Zagreb, Božidar Širola, who had visited the Folklore Institute at the invitation of the Music Society and prepared a detailed report on the institute's work and achievements, ${ }^{58}$ in particular the collected material, the cataloguing system and the library.

There is very little data or preserved documentation about the work of the institute - which was taken over from the Music Society by the Drava banovina administration in Ljubljana on 1 September 1940 and was renamed the Institute of Ethnomusicology, operating as a special division within the Department of Education - during the occupation (1941-1945). The work of the institute during this period can, however, be briefly summarised through Marolt's words from later reports: following the occupation in April 1941, the institute's collection-related work ceased and the focus shifted to organising, classifying and transcribing the material, in particular the collection of Slovenian folk songs with melodies kept by the Ethnographic Museum in Ljubljana. There are no preserved documents from this period mentioning any sort of sound material.

After the liberation in May 1945, work at the institute gained fresh momentum, as revealed by many preserved archival documents. During the first few months, the institute was part of the newly established Ministry of Education along with other divisions of the former Department of Education, before joining the Academy of Music as the Institute of Ethnomusicology in early 1946. A new collection, i.e., a collection of gramophone records, is already mentioned in the first post-war reports.

In a document entitled Report, Plans and Proposals dated 24 May 1945, ${ }^{59}$ i.e., immediately after the liberation, Marolt reported in detail to the National Government of Slovenia (Narodna vlada Slovenije, NVS) about the material kept by the institute, mentioning "50 phonograph discs" for the first time. In a short letter dated 30 July 1945, ${ }^{60}$ sent by Marolt to the Ministry of Education to report some statistical data with regard to the institute's work, he mentions, among other things, a collection of "50 double-sided phonograph

58 Božidar Širola visited the Folklore Institute in February 1940 and prepared a 17-page report about the visit, giving some concrete suggestions regarding the institute's work and his opinion on how it should be reorganised (NUK, Glasbena zbirka, Glasbena matica Ljubljana, mapa Glasbena matica/Folklorni inštitut, Izveštaj o pregledu Folklornog instituta Glazbene Matice u Ljubljani, 25. 2. 1940).

59 ZRC SAZU, Glasbenonarodopisni inštitut, arhivsko gradivo, strokovna in uradna korespondenca, Urd. koresp. 64/2-45-esc.

60 ZRC SAZU, Glasbenonarodopisni inštitut, arhivsko gradivo, strokovna in uradna korespondenca, Urd. koresp. 73/45-esc. 
discs". Moreover, in a report on the institute's work and future plans in January 1946, ${ }^{61}$ Marolt lists "59 double-sided Gewaert ${ }^{62}$ Gevaphon /30 phonograph discs", which include "118 original recordings of typical examples of sound folklore". A more specific date of exactly when the institute acquired the records has not been found, but it appears that this was during the war. It is not, however, evident that these were the recordings made during Marolt's Radio Ljubljana lectures. The only document that gives a more exact period of when the gramophone recordings were acquired is the institute's work report for the period "from 9 May to 31 December 1945", ${ }^{63}$ which states that during this period the institute obtained " 23 gramophone recordings of folk songs and rituals". Since this is the number of recordings and not the number of discs, only a rough estimate can be made of how many double-sided gramophone records there were: assuming there was one recording on each side of the record, 11-12 new records were probably acquired. The total number of records listed in May 1945 (50) and an estimate of the ones obtained by the end of that year (11-12) would thus roughly correspond to the number 59, which was specified at the beginning of 1946.

Marolt planned to resume field recording immediately after the liberation. His "plans for the near future" in early $1946^{64}$ included "sound recording and photography of the instrumental groups Kociper and Tratnik" (from the region of Prekmurje) and "the instrumental group Zubalič" (from Istria). Since it was not possible for the sound documentation to be done by the institute itself, as it did not yet have its own recording device, the plan was to undertake the recording "in cooperation with the NVS Phonosection". However, none of the planned recording sessions took place, as no recordings of the aforementioned performers have been preserved at the institute, and Marolt makes no mention of these field recordings or any recorded material in later reports.

In 1946, Marolt was involved in the preparation of new recordings for gramophone records. In a monthly report for January $1946,{ }^{65}$ he noted that "for the purposes of Carinthian political propaganda, the institute took over the organisation and preparation of the means that would serve the purposes of the propaganda", including "phonograph discs, sheet music and ethnographical

61 ZRC SAZU, Glasbenonarodopisni inštitut, arhivsko gradivo, strokovna in uradna korespondenca, Urd. koresp. $4 / 46$.

62 The name of the company is often misspelled in the preserved documents; the correct company name is Gevaer.

63 ZRC SAZU, Glasbenonarodopisni inštitut, arhivsko gradivo, strokovna in uradna korespondenca, Urd. koresp. 64/46-exc.

64 ZRC SAZU, Glasbenonarodopisni inštitut, Urd. koresp. 4/46.

65 ZRC SAZU, Glasbenonarodopisni inštitut, arhivsko gradivo, strokovna in uradna korespondenca, Urd. koresp. 7/46. 
albums". The April 1946 report $^{66}$ explained in more detail that in addition to arrangements of some partisan and folk songs (8,000 copies), the institute had also prepared "eight additional double-sided phonograph discs". It is not clear from the preserved documents whether copies of the records in question were included in the institute's collection.

During this period, Marolt also planned the purchase of a large number of records for future sound documentation. Thus, a preliminary estimate of costs for $1947^{67}$ stated that the institute was planning to purchase 50 Gevaert Gevaphon phonograph discs for "documentary folkloristic cases" and specified the cost of recording based on an estimate by the "SNOS Phonosection". It was also emphasised that the purchase of "an electric rotor with an amplifier for phonoreproduction of the institute's phonograph discs" was imperative, as phonograph discs were "the key testament to our sound folklore" and "the purchase of this device was therefore one of the institute's most important equipment-related matters and needed to be made as soon as possible". The "electric rotor" referred to an electrically powered gramophone, and Radio Ljubljana already owned one of these at that time. In the end, the institute did not buy a record reproduction device and it is most likely that the purchase and recording of gramophone records in cooperation with the aforementioned "SNOS Phonosection" did not take place either, as there are no preserved reports of any newly recorded material.

In 1947, Marolt again started working more closely with Radio Ljubljana. For a while, he was even in their employ as a music editor - a part-time job involving five hours per day - and later for some time also as the choirmaster of the radio's choir. As part of his new job, he became familiar with radio recording equipment, and was involved in the preparation of Slovenian folk songs for radio stations in Moscow, Belgrade and Prague. He often came across various previously recorded gramophone records with Slovenian folk songs. Among other things, he was asked to review the gramophone records with Slovenian songs that were included in the Jugoton record company's 1947 sales catalogue. He reviewed the recordings and recommend purchasing some of them, preferably several copies: "I suggest buying multiple copies as they have documentary value, and are likely to be sold out, and also, single copies will get scuffed very quickly." ${ }^{68}$ Among the reviewed records were five records with ten recordings of Carinthian folk songs from Rosental performed by the Brnica sextet, which Jugoton still had in stock but no longer featured in the

66 ZRC SAZU, Glasbenonarodopisni inštitut, arhivsko gradivo, strokovna in uradna korespondenca, Urd. koresp. 22/46.

67 ZRC SAZU, Glasbenonarodopisni inštitut, arhivsko gradivo, strokovna korespondenca, Strok. k. 63/46.

68 ZRC SAZU, Glasbenonarodopisni inštitut, arhivsko gradivo, strokovna korespondenca, Strok. k. $12 / 48$. 
sales catalogue. One possible reason for this might be that the records still had the Elektroton ${ }^{69}$ label. Marolt had the following to say about the records: "These Elektroton records are a recording of original folk songs performed by authentic folk singers. Diction, singing and performance are good, the phonoreproduction is satisfactory" ${ }^{70} \mathrm{He}$ added that the records dated back to the pre-war period, but were well preserved.

The preserved documents do not include any information about the institute obtaining any gramophone records from Radio Ljubljana while Marolt was employed at the radio. However, some of the preserved records in the institute's gramophone collection are undoubtedly related to this period. For instance, the present-day collection includes all five records by the Brnica sextet with the Elektroton label, which Marolt suggested Radio Ljubljana should buy in 1948 .

\section{The number of records in the collection}

Data about the number of gramophone records included in the institute's collection varies considerably in different periods and documents. At the first mention of the institute's gramophone record collection in the spring of 1945, 50 records were mentioned, and in the end-of-year report 59. All of the records supposedly had the "Gevaert Gevaphon" label. An inventory of archival material dated 8 January $1947,{ }^{71}$ made to assess the insurance value of the material, lists 63 record without mentioning the label, which is usually omitted from later documents as well. Despite some concrete plans for future recordings mentioned in archival reports and documents from this period, no detailed data or documents about such recordings have been preserved, which suggests they did not take place. Nor are there any clear reports or data indicating that the institute acquired any new sound material during that time or when this was supposed to happen.

The next available data about the number of records is found two years later, in a report on the state of the institute's library (8 May 1950). ${ }^{72}$ According to this report, a special library collection contained no fewer than 83 double-sided records, which is the maximum number of records in this collection

69 Elektroton was the only gramophone record company in Slovenia in the interwar period. It was actually a craft workshop with a single hand-operated record press for pressing gramophone records of mostly foreign matrices. The company had its own shop on the ground floor of the famous Nebotičnik building in Ljubljana. In 1938, it relocated to Zagreb, where it continued its operation under the same name. After the war, in 1947, it was nationalised and renamed Jugoton (for more about the beginnings of the gramophone industry in Slovenia, see Drago Kunej, "Slovenski posnetki na gramofonskih ploščah z 78 o/min,” Traditiones 43, no. 2 (2014): 11-29, https:// doi.org/10.3986/Traditio2014430201).

70 ZRC SAZU, Glasbenonarodopisni inštitut, Strok. k. 12/48.

71 ZRC SAZU, Glasbenonarodopisni inštitut, arhivsko gradivo, strokovna korespondenca ad2/1-47.

72 ZRC SAZU, Glasbenonarodopisni inštitut, arhivsko gradivo, strokovna korespondenca 16/50. 
mentioned in any preserved documents. This is most likely the number of all of the records in the collection and not just the records with Slovenian music.

Later documents mainly list Slovenian sound material, so the number of records is smaller. In 1952, after Marolt's death, the record collection was first mentioned in more detail in response to a letter from Natko Devčić, ${ }^{73}$ who was collecting data for the International Folk Music Council (IFMC) to be used in an "international catalogue of gramophone records with authentic musical folklore”. On 29 May 1952, the Institute of Ethnomusicology replied ${ }^{74}$ to Devčić, explaining that its "collection of folkloristic material contained 18 gramophone records with recordings of authentic musical folklore". The letter also mentions "22 gramophone records with recordings of folk songs and rituals, mostly arrangements by folklorists Marolt and Tomc", explaining that the recorded material was mostly from the regions of Koroška (Carinthia), Štajerska (Styria) and Dolenjska (Lower Carniola). The report thus lists a total of 40 gramophone records, which is a selection of "authentic recordings". No other details about the selected recordings are provided. An extensive and detailed Report on Work in the Field of Folklore in Slovenia, ${ }^{75}$ published later that year, lists a sound collection of "58 phonograph discs with typical Slovenian songs" as one of the institute's archival collections; however, the collection is not presented in detail.

The most detailed list of gramophone records from this period is provided on two forms ${ }^{76}$ that were filled out by the institute in 1953 at the specific request of the International Folk Music Council (IFMC), which had not received the data that was supposed to be passed on to them by Natko Devčic the previous year. In an accompanying letter, the institute explains that this time only "authentic examples" of folk music recorded on 23 records are included on the forms. The letter is accompanied by a detailed inventory of all of the records including the title of the recording and the type of the record (label) and its code number. This time, an even shorter list of seven records is added covering recordings of folk song arrangements by Marolt, Švikaršič and Kernjak that are considered "equivalent arrangements", that is, arrangements equivalent to "authentic" recordings. For the first time, the list includes more detailed data for 30 records with Slovenian folk music that are part of the institute's record collection; as before, this is a selection of "authentic recordings". Only 30 "authentic" recordings in total are listed this time, as opposed to 40 the year before.

73 ZRC SAZU, Glasbenonarodopisni inštitut, arhivsko gradivo, strokovna korespondenca 13/52.

74 ZRC SAZU, Glasbenonarodopisni inštitut, arhivsko gradivo, strokovna korespondenca 13/1-52.

75 The report was prepared in August 1952 for the purposes of a planned publication on musical folklore in Yugoslavia, which had been initiated by the Yugoslav Musical Folklore Committee, established on 1 July 1952 in Belgrade as part of the Yugoslav National Commission for UNESCO (ZRC SAZU, Glasbenonarodopisni inštitut, arhivsko gradivo, strokovna korespondenca 20/9-52).

76 ZRC SAZU, Glasbenonarodopisni inštitut, arhivsko gradivo, strokovna korespondenca, Strok. k. 31/4-53. 
Today, this collection includes 69 double-sided gramophone records, of which 55 feature Slovenian material, while the remaining 14 records contain foreign musical material, mostly arrangements of Russian and Ukrainian folk songs. Of the 30 records listed in 1953, almost all (except two) are preserved in the collection. In addition to this, the present-day collection includes a few records with duplicated songs, which are also recorded on discs with a different label. Therefore, the number of records with Slovenian songs is now higher than in 1953, when the records with duplicated songs were not included in the list. This suggests that in terms of the number of records, the collection has probably not changed much, although over time this could happen due to damage, destruction or loss.

\section{The labels and type of records}

While the oldest documents reveal that all of the records are identical and have the "Gevaert Gevaphon"77 label, later reports no longer mention the types of records or labels. It is, however, evident from various other preserved documents that most of the records were recorded at Radio Ljubljana. In one of his later letters, Marolt specified a recording device he had used for test recordings in one of his ethnomusicological courses, namely the "Telefunken-TonfolienSchneid-und Wiedergabegerät ELA A 107/1", one of which was owned by Radio Ljubljana at the time. ${ }^{78}$

The preserved records that are part of the collection confirm the archival documents' statements according to which they were recorded by means of so-called direct cut recording technology (sound carriers are often called instantaneous discs, ${ }^{79}$ German: Tonfolien), which was widely used from the

77 The Belgian company Gevaert \& Co was founded by Lieven Gevaert (1868-1935) in 1894. A1though the company specialised in photographic material, it also produced records (under the Gevaphone label) and needles for gramophones. In 1964, Gevaert merged with Agfa to become Agfa Gevaert.

78 ZRC SAZU, Glasbenonarodopisni inštitut, Zn. dps. 104/1, 1940.

79 The most widespread type of instantaneous disc is laminated: the lacquer or "acetate" disc. A lacquer coating consisting mainly of cellulose nitrate and usually plasticised with castor oil or camphor carries the information. The substrate that supports the information layer of the discs is generally made of metal (e.g., aluminium or zinc), but sometimes also of glass, cardboard or paper. Lacquer or "acetate" discs are highly sensitive and unstable. Even when these discs are playable they are at grave risk of suddenly cracking or crazing without warning. The reason for this is the steadily increasing stress between the lacquer coating and the supporting base plate. This stress is generated by shrinkage of the lacquer coating. Lacquer discs should therefore be given the highest priority in the sound archive preservation programme (see also IASA Technical Committee, The Safeguarding of the Audiovisual Heritage: Ethics, Principles and Preservation Strategy, eds. Will Prentice and Lars Gaustad, Version 4, 2017 (Standards, Recommended Practices and Strategies, IASA-TC 03), International Association of Sound and Audiovisual Archives; IASA Technical Committee, Guidelines on the Production and Preservation of Digital Audio Objects, ed. Kevin Bradley, Second edition 2009, (Standards, Recommended Practices and Strategies, IASA-TC 04), International Association of Sound and Audiovisual Archives). 
1930s to the late 1950s for recording and broadcasting purposes. The discs were used to record and replay signals without the need for galvanoplastic processing and pressing. Their surfaces are soft enough to permit the cutting of the groove, but hard enough to permit a number of replays. Most of these discs are unique recordings. If not recognisable by their distinct appearance, almost all instantaneous discs can be identified by their handwritten or typed labels.

Instantaneous discs were produced in very small quantities using elementary cutting machines. They were widely used for a range of purposes, especially at radio stations, before magnetic tape recorders became common. Around 1940, disc recorders designed for amateur use began appearing on the market, but their sales were limited due to high prices. World War II subsequently brought their production to a halt. After the war, the popularity of such recorders greatly increased. In the 1950s, direct cut recording technology was replaced by magnetic tape recording.

Today, the collection of gramophone records at the Institute of Ethnomusicology consists of mostly instantaneous discs: out of a total of 55 records with recordings featuring Slovenian material, only the aforementioned five records by the Brnica sextet are non-instantaneous discs (shellac records with the Elektroton label), which were also intended for general sale. The two most common instantaneous disc labels are Gevaphone (23 records) and Dea (18 records), while eight others have the Radio Ljubljana label and another one the Binsa label.

\section{Marolt's endeavours to purchase a magnetic tape recorder}

The quantity of preserved documents related to gramophone records or sound documentation from 1948 and 1949 is rather limited. During this period, Marolt was active in various fields, including work related to the newly established folk dance ensemble, as well as "folklore lectures" at the Academy of Music. In the latter, he always emphasised the important role sound and film recording played in ethnographic work, aiming to provide his students with the necessary knowledge as part of practical work. However, he was constantly plagued by financial difficulties and inadequate technical equipment, as revealed by various work reports. To make matters worse, he suffered a partial stroke in June 1949, which kept him bedridden for almost a year.

However, even while ill and not yet fully recovered from the stroke, Marolt worked occasionally. For instance, in a letter sent to the Ministry of Science and Culture on 9 January 1950, a magnetic tape recorder was first mentioned as a sound recording and reproducing device that was part of the necessary equipment the institute was planning to buy to equip a lecture hall for its "cultural and educational work". In the spring of 1950, Marolt recovered completely, 
and in a letter dated 27 April $1950^{80}$ he mentions a specific tape recorder he wanted in addition to all of the other devices he was planning to buy "for the scientific research of musical and dance folklore and lectures", namely "a magnetic tape recorder for speech and music - BRUSH SOUND MIRROR TAPE RECORDER, BK-403 model with a wire and a reproducer". The tape recorder was supposed to arrive from "overseas"; however, it is not entirely clear whether the recorder in question was a tape recorder or a wire recorder, the latter being more widespread at the time (from 1946 onwards such devices were also intended for home use). In any case, Marolt's intention to buy a recording device based on the principle of magnetic sound recording - as opposed to a sound recording device that used records - was expressed very clearly.

Just one month later, Marolt mentioned another magnetic tape recorder model that the institute could get with the help of "Dr Foerster from Switzerland”, i.e., "a Revere Magnetofon” priced at 1200 francs. Quite a lot of documentation has been preserved regarding the purchase of this particular piece of equipment. Marolt strongly demanded the purchase of this much-needed equipment, asking for the necessary funds:

For the third year in a row, the Institute of Ethnomusicology has been planning the purchase of the equipment it so desperately needs for scientific purposes. [...] In the world of science, the use of this sort of equipment has long been standard practice. Without this auxiliary device [...], it will be impossible to critically collect folklore-related material using the methods of dialectical materialism in the future. ${ }^{81}$

Marolt also pointed out that "in terms of its quality, the device needs to correspond to the latest scientific achievements; as far as that is concerned, such a device is unattainable in the socialist as well as in the private sectors of the Federal People's Republic of Yugoslavia”. ${ }^{82}$ Despite the fact that a specific model had already been selected and a quote obtained, and notwithstanding Marolt's compelling arguments and urgent appeals, the purchase fell through. It took a few more years for the institute to actually obtain the recording device, which was too late for Marolt, who died of a heart attack on 6 April 1951.

\section{Conclusion}

Throughout his research career, from the time the institute was established in 1934 until his death in 1951, Marolt made a great deal of effort to acquire a recording device to be owned by the Institute of Ethnomusicology. He was constantly on the lookout for the most suitable recording device for "scientific work" and for information about advancements in recording technology. First,

80 ZRC SAZU, Glasbenonarodopisni inštitut, arhivsko gradivo, strokovna korespondenca 30/50.

81 ZRC SAZU, Glasbenonarodopisni inštitut, arhivsko gradivo, strokovna korespondenca 13/1-50.

82 Ibid. 
he wanted to take up sound recording work where the Committee for the Collection of Slovenian Folk Songs (OSNP) had left off due to World War I, and to undertake sound documentation work using a simple Edison phonograph. He was well acquainted with the OSNP Committee's work and material, as he had helped organise it while assisting Stanko Vurnik, an associate of the Ethnographic Museum, who was, according to Marolt, "the only scientific ethnographer in Slovenia who was also musically educated" and whose "untimely death thwarted his ambitious plans" ${ }^{83}$ Marolt had the following to say about the work at the newly established institute: "I actually started where the late Dr Stanko Vurnik had stopped". ${ }^{84}$

Marolt soon realised, however, that modern and higher-quality recording devices recorded sound on gramophone records or even sound film and were quite expensive. Due to a constant lack of funds, he was unable to acquire any such devices for the institute. The preserved documents thus show that the earliest sound recordings on gramophone records were made in collaboration with Radio Ljubljana, for which he prepared a series of educational radio lectures in 1936/37. During his further cooperation with Radio Ljubljana after World War II, Marolt often worked with gramophone records; however, none of the preserved documents specifically mention that any gramophone records were obtained by the institute from the radio in that period. Towards the end of his life, he focused his efforts on purchasing a magnetic tape recorder, a new sound recording technology that was just coming onto the market, but to no avail. Thus, the recordings on gramophone records remain the only sound documents in the creation of which Marolt was involved.

The agreement according to which a copy of the recorded samples on gramophone records from lectures presented in 1936/1937 was to be given to the institute could thus be considered the foundation of the institute's gramophone record collection. However, it took a few more years for the institute to acquire such a collection and no documents have been preserved to explain in more detail how and when individual records actually came into the institute's possession. Moreover, the records are not dated, which is a common problem with older gramophone records. ${ }^{85}$ It therefore comes as somewhat of a surprise in the reports after the end of World War II that in the spring of 1945 , i.e., immediately following the liberation, the institute already had a collection of 50 gramophone records (59 at the end of the year), and even more so that all of the records had a Gevaphone label. In fact, today, the collection contains only 23 Gevaphone records, which suggests that most of the 59 records were later either destroyed or lost, as they are no longer part

\section{ZRC SAZU, Glasbenonarodopisni inštitut, Zn. dps. 18/10, 1935.}

Ibid.

See also Drago Kunej,“Medkodamiskritazvočna dediščina Slovencev, «GlasnikSlovenskegaetnološkega društva 54, no. 1-2 (2014): 22-28, http://www.dlib.si/?URN=URN:NBN:SI:DOC-XOJUD3US. 
of the collection. On the other hand, a comparison of the 1953 inventory listing 30 records in the collection shows that almost all of the listed records have been preserved to this day. Due to the lack of more detailed data on selected examples that Marolt included in his lectures, it has not been possible to make a more reliable comparison with the material preserved on the records and to conclude how many records with possible recordings of prewar lectures have been preserved.

The collection of preserved records represents a special type of instantaneous disc that was made by means of direct cut recording technology. These are unique recordings that exist in a single copy - as pointed out in an institute letter as early as $1953^{86}$ - which gives them special documentary value. The recordings feature various performances of folk songs, often arranged by France Marolt and performed by "his" Academic choir under his artistic direction, which gives the recordings even greater documentary value.

Archival documents and the recordings preserved on gramophone records not only reveal Marolt's efforts to acquire a recording device and his plans for it to be used for research, educational and artistic purposes, but also serve to illustrate his views on folk music. Marolt's aim was to research, understand and get to the roots of folk music, as well as to "restore" it and present it in its "real" and "authentic" form, the way he had envisioned and created it. The preserved recordings on unique gramophone records thus provide resounding proof of how he viewed folk music and its "authenticity". As a matter of fact, most likely not only how he viewed it, but how other experts in the field viewed it at the time, as well. Thus, according to the institute's researchers who followed in Marolt's footsteps after his death, "authentic" recordings of folk music on gramophone records also include the recordings of various folk song arrangements (e.g., by Marolt, Švikaršič, Tomc, Kernjak). The researchers believe that "typical Slovenian characteristics" have been preserved in these arrangements, which makes them almost equivalent to authentic recordings ${ }^{87}$ However, they also believe that the "real authentic" recordings are mainly "restored" and arranged musical examples and songs performed by the singers of "Marolt's" choir and presented as staged and "directed" reconstructions of various customs and habits, such as the Štehvanje tournament, the Rej dance under a linden tree (Rej pod lipo), the Gailtal wedding (Ziljska ohcet) and the Visoči rej dance. 


\section{Sources}

NUK. Glasbena zbirka. Glasbena matica Ljubljana. Mapa Glasbena matica/Folklorni inštitut. Zapisnik II. seje odseka instituta za raziskovanje glasbenega folklora, 22.12.1934.

NUK. Glasbena zbirka. Glasbena matica Ljubljana. Mapa Glasbena matica/Folklorni inštitut. Glasbena Matica v Ljubljani predlaga Akademiji znanosti in umetnosti v Ljubljani, da prevzame Folklorni institut Glasbene Matice. 22. 5. 1939.

NUK. Glasbena zbirka. Glasbena matica Ljubljana. Mapa Glasbena matica/Folklorni inštitut. Izveštaj o pregledu Folklornog instituta Glazbene Matice u Ljubljani. 25. 2. 1940.

NUK. Glasbena zbirka. Glasbena matica Ljubljana. Zapisniki odborovih sej od 14. 6. 1921 do 24.1.1936. Zapisnik 6. odborove seje, 31.8.1934.

NUK. Glasbena zbirka. Glasbena matica Ljubljana. Zapisniki odborovih sej od 14. 6. 1921 do 24.1. 1936. Zapisnik 7. odborove seje, 14.9.1934.

ZRC SAZU, Glasbenonarodopisni inštitut. Arhivsko gradivo. Strokovna in uradna korespondenca, Urd. dps. 8/7, 1934.

ZRC SAZU, Glasbenonarodopisni inštitut. Arhivsko gradivo. Strokovna in uradna korespondenca, Urd. dps. 10/1, 1935.

ZRC SAZU, Glasbenonarodopisni inštitut. Arhivsko gradivo. Strokovna in uradna korespondenca, Urd. dps. 12/a, b, 1935.

ZRC SAZU, Glasbenonarodopisni inštitut. Arhivsko gradivo. Strokovna in uradna korespondenca, Urd. dps. 13/1, 1935.

ZRC SAZU, Glasbenonarodopisni inštitut. Arhivsko gradivo. Strokovna in uradna korespondenca, Urd. dps. 42/4, 1936.

ZRC SAZU, Glasbenonarodopisni inštitut. Arhivsko gradivo. Strokovna in uradna korespondenca, Urd. dps. 45/1, 1936.

ZRC SAZU, Glasbenonarodopisni inštitut. Arhivsko gradivo. Strokovna in uradna korespondenca, Urd. dps. 55/2, 1937.

ZRC SAZU, Glasbenonarodopisni inštitut. Arhivsko gradivo. Strokovna in uradna korespondenca, Urd. dps. 72/4, 1938.

ZRC SAZU, Glasbenonarodopisni inštitut. Arhivsko gradivo. Znanstvena korespondenca, Zn. dps. 1/1(1), 1934.

ZRC SAZU, Glasbenonarodopisni inštitut. Arhivsko gradivo. Znanstvena korespondenca, Zn. dps. 2/1(1), 1934.

ZRC SAZU, Glasbenonarodopisni inštitut. Arhivsko gradivo. Znanstvena korespondenca, Zn. dps. 3/2(1), 1934.

ZRC SAZU, Glasbenonarodopisni inštitut. Arhivsko gradivo. Znanstvena korespondenca, Zn. dps. 17/1(2), 1935.

ZRC SAZU, Glasbenonarodopisni inštitut. Arhivsko gradivo. Znanstvena korespondenca, Zn. dps. 18/10, 1935.

ZRC SAZU, Glasbenonarodopisni inštitut. Arhivsko gradivo. Znanstvena korespondenca, Zn. dps. 20/1, 1936.

ZRC SAZU, Glasbenonarodopisni inštitut. Arhivsko gradivo. Znanstvena korespondenca, Zn. dps. 22/1, 1936.

ZRC SAZU, Glasbenonarodopisni inštitut. Arhivsko gradivo. Znanstvena korespondenca, Zn. dps. 60/1,1937.

ZRC SAZU, Glasbenonarodopisni inštitut. Arhivsko gradivo. Znanstvena korespondenca, Zn. dps. 66/1, 1937.

ZRC SAZU, Glasbenonarodopisni inštitut. Arhivsko gradivo. Znanstvena korespondenca, Zn. dps. 48/1, 1936. 
ZRC SAZU, Glasbenonarodopisni inštitut. Arhivsko gradivo. Znanstvena korespondenca, Zn. dps. 50/5, 1936.

ZRC SAZU, Glasbenonarodopisni inštitut. Arhivsko gradivo. Znanstvena korespondenca, Zn. dps. 55/1, 1937.

ZRC SAZU, Glasbenonarodopisni inštitut. Arhivsko gradivo. Znanstvena korespondenca, Zn. dps. 59/1, 1937.

ZRC SAZU, Glasbenonarodopisni inštitut. Arhivsko gradivo. Znanstvena korespondenca, Zn. dps. 104/1, 1940.

ZRC SAZU, Glasbenonarodopisni inštitut. Arhivsko gradivo. Strokovna in uradna korespondenca, Urd. dps. 81/2, 1939.

ZRC SAZU, Glasbenonarodopisni inštitut. Arhivsko gradivo. Strokovna in uradna korespondenca, Urd. dps. 111/1, 1940.

ZRC SAZU, Glasbenonarodopisni inštitut. Arhivsko gradivo. Strokovna in uradna korespondenca, Urd. dps. 112/1, 1939.

ZRC SAZU, Glasbenonarodopisni inštitut. Arhivsko gradivo. Strokovna in uradna korespondenca, Urd. koresp. 64/2-45-esc.

ZRC SAZU, Glasbenonarodopisni inštitut. Arhivsko gradivo. Strokovna in uradna korespondenca, Urd. koresp. 73/45-esc.

ZRC SAZU, Glasbenonarodopisni inštitut. Arhivsko gradivo. Strokovna in uradna korespondenca, Urd. koresp. 4/46.

ZRC SAZU, Glasbenonarodopisni inštitut. Arhivsko gradivo. Strokovna in uradna korespondenca, Urd. koresp. 64/46-exc.

ZRC SAZU, Glasbenonarodopisni inštitut. Arhivsko gradivo. Strokovna in uradna korespondenca, Urd. koresp. 7/46.

ZRC SAZU, Glasbenonarodopisni inštitut. Arhivsko gradivo. Strokovna in uradna korespondenca, Urd. koresp. 46/46.

ZRC SAZU, Glasbenonarodopisni inštitut. Arhivsko gradivo. Strokovna korespondenca, Strok. k. 63/46.

ZRC SAZU, Glasbenonarodopisni inštitut. Arhivsko gradivo. Strokovna korespondenca, Strok. k. 12/48.

ZRC SAZU, Glasbenonarodopisni inštitut. Arhivsko gradivo. Strokovna korespondenca $\operatorname{ad} 2 / 1-47$

ZRC SAZU, Glasbenonarodopisni inštitut. Arhivsko gradivo. Strokovna korespondenca $16 / 50$.

ZRC SAZU, Glasbenonarodopisni inštitut. Arhivsko gradivo. Strokovna korespondenca $13 / 52$.

ZRC SAZU, Glasbenonarodopisni inštitut. Arhivsko gradivo. Strokovna korespondenca 13/1-52.

ZRC SAZU, Glasbenonarodopisni inštitut. Arhivsko gradivo. Strokovna korespondenca 20/9-52.

ZRC SAZU, Glasbenonarodopisni inštitut. Arhivsko gradivo. Strokovna korespondenca, Strok. k. 31/4-53.

ZRC SAZU, Glasbenonarodopisni inštitut. Arhivsko gradivo. Strokovna korespondenca 30/50.

ZRC SAZU, Glasbenonarodopisni inštitut. Arhivsko gradivo. Strokovna korespondenca 13/1-50. 


\section{Bibliography}

“Širola, Božidar.” In Hrvatska enciklopedija. Leksikografski zavod Miroslav Krleža, 2020. Accessed 24 June 2020. http://www.enciklopedija.hr/Natuknica.aspx?ID=59596.

Barbo, Matjaž. Slovenska muzikologija: Kratek prelet po zgodovini. Ljubljana: Znanstvena založba Filozofske fakultete, 2019.

Bufon, Zmagoslav. “Škerlj, Božo (1904-1961).” Slovenska biografija. Slovenska akademija znanosti in umetnosti, Znanstvenoraziskovalni center SAZU, 2013. Accessed 22 June 2020. http://www.slovenska-biografija.si/oseba/sbi654107/\#slovenski-biografski-leksikon. Originally published in: Slovenski biografski leksikon, 11. zv. Stelè - Švikaršič. Alfonz Gspan et al. Ljubljana: Slovenska akademija znanosti in umetnosti, 1971.

Cigoj Krstulović, Nataša. "Prizadevanja Glasbene matice za ohranitev in oživitev etničnega repertoarja ter ustanovitev Instituta za raziskovanje slovenske glasbene folklore leta 1934." Traditiones 43, no. 2 (2014): 213-236. https://doi.org/10.3986/TradITIO 2014430211.

Cvetko, Dragotin. “Šijanec, Drago Mario (1907-1986).” Slovenska biografija. Slovenska akademija znanosti in umetnosti, Znanstvenoraziskovalni center SAZU, 2013. Accessed 24 June 2020. http://www.slovenska-biografija.si/oseba/sbi648279/\#slovenski-biografski-leksikon. Originally published in: Slovenski biografski leksikon, 11. zv. Stelè - Švikaršič. Alfonz Gspan et al. Ljubljana: Slovenska akademija znanosti in umetnosti, 1971.

IASA Technical Committee. Guidelines on the Production and Preservation of Digital Audio Objects, edited by Kevin Bradley. $2^{\text {nd }}$ edition 2009. (Recommended Practices and Strategies, IASA-TC 04). International Association of Sound and Audiovisual Archives.

IASA Technical Committee. The Safeguarding of the Audiovisual Heritage: Ethics, Principles and Preservation Strategy, edited by Will Prentice and Lars Gaustad. Version 4, 2017. (Standards, Recommended Practices and Strategies, IASA-TC 03). International Association of Sound and Audiovisual Archives.

Kumer, Zmaga. "France Marolt (1891-1951): Ob stoletnici rojstva slovenskega etnomuzikologa." Traditiones 20, (1991): 9-28. http://www.dlib.si/?URN=URN:NBN:SI: DOC-BDE0OZFP.

Kumer, Zmaga. “Ustanovitev in razvoj do jeseni leta 1999.” In 65 let Glasbenonarodopisnega inštituta ZRC SAZU: 1934-1999, edited by Marko Terseglav, 11-26. Ljubljana: Založba ZRC, ZRC SAZU, 2000.

Kumer, Zmaga. Ob 50-letnici ustanovitve Folklornega inštituta. Ljubljana: ZRC SAZU, Inštitut za slovensko narodopisje, 1984.

Kunej, Drago. "Fonografski posnetki slovenskih ljudskih pesmi iz Bele krajine v SEM: Rezultat lastnih snemanj ali pridobljeno gradivo OSNP?” Etnolog 19 (2009): 225-235. http://www.dlib.si/?URN=URN:NBN:SI:DOC-4XVJMEM1.

Kunej, Drago. "Med kodami skrita zvočna dediščina Slovencev." Glasnik Slovenskega etnološkega društva 54, no. 1-2 (2014): 22-28. http://www.dlib.si/?URN=URN:NBN:SI: DOC-XOJUD3US.

Kunej, Drago. "Pesemsko izročilo Bele krajine na zgodnjih terenskih posnetkih." Traditiones 46, no. 3 (2017): 125-140. https://doi.org/10.3986/Traditio2017460307.

Kunej, Drago. “Slovenski posnetki na gramofonskih ploščah z 78 o/min.”Traditiones 43, no. 2 (2014): 11-29. https://doi.org/10.3986/Traditio2014430201.

Kunej, Drago. "We have plenty of words written down, we need melodies!: The purchase of the first recording device for ethnomusicological research in Slovenia." Traditiones 34, no. 1 (2005): 125-140. https://doi.org/10.3986/Traditio2005340110. 
Misson, Andrej. "Nekaj misli o slovenskem zborovskem skladanju med obema svetovnima vojnama." In Studia musicologica Labacensia, Nova glasba v "novi” Evropi med obema svetounima vojnama, edited by Jernej Weiss, 239-256. Koper: Založba Univerze na Primorskem, Festival Ljubljana, 2018. https://doi.org/10.26493/978-961-7023-72-5.239-256.

Pettan, Svanibor. “Josip Široki - prvi hrvatski doktor muzikologije,” Od-Do 4, no. 35 (1982): 4-6.

Tiefenthaler, Vera. "Josip Široki: singer and transcriber at the same time: An analysis of his aims, methods, and findings." Traditiones 34, no. 1 (2005): 91-99. https://doi. org/10.3986/Traditio2005340107.

\section{POVZETEK}

\section{Prizadevanja Franceta Marolta za zvočno dokumentiranje ljudske glasbe}

France Marolt (1891-1951) je bil v svoji vsestranski dejavnosti vseskozi močno povezan s slovensko glasbo in preučevanjem ljudske kulture. Njegovo raziskovalno in umetniško delo je bilo že večkrat obravnavano in ovrednoteno ter je v strokovnih krogih razmeroma dobro poznano. Namen članka je predstaviti in osvetliti njegova prizadevanja za pridobitev snemalnih naprav, s katerimi je želel zapisovati in dokumentirati ljudsko glasbo na terenu in jih uporabljati tako pri svojem raziskovalnem delu, kakor tudi pri predavanjih in drugih oblikah izobraževalnega in kulturnega delovanja. Raziskava se pri tem opira predvsem na preučevanje različnih poročil, dopisov in drugih arhivskih virov ter na ohranjene gramofonske plošče.

Marolt se je pri svojem umetniškem in raziskovalnem delu že zgodaj zavedal velikega pomena zvočnega dokumentiranja glasbenonarodopisnega gradiva. V vsem času svojega profesionalnega raziskovalnega dela si je prizadeval pridobiti lastno snemalno napravo za Glasbenonarodopisni inštitut; od ustanovitve inštituta leta 1934 do svoje smrti leta 1951. Pri tem je vseskozi iskal najprimernejšo snemalno napravo za "znanstveno delo« in zbiral podatke o razvoju snemalne tehnologije. Najprej je želel z zvočnimi snemanji nadaljevati tam, kjer je zaradi 1. sv. vojne končal Odbor za nabiranje slovenskih narodnih pesmi in zvočno dokumentirati s preprostim Edisonovim fonografom, kmalu pa je spoznal, da sodobne in kakovostne snemalne naprave zapisujejo na gramofonske plošče ali celo na zvočni film in magnetofonski trak in so precej drage. Zaradi stalnega pomanjkanja finančnih sredstev za inštitut takšnih naprav ni mogel zagotoviti, zato ohranjena dokumentacija kaže, da so njegovi prvi in edini zvočni posnetki nastali na gramofonskih ploščah in $\mathrm{v}$ sodelovanju $\mathrm{z}$ Radiem Ljubljana, za katerega je v letih 1936/37 pripravil serijo izobraževalnih oddaj. Dogovor, da kopijo posnetih primerov na gramofonskih ploščah s predavanj v letih 1936/1937 dobi tudi inštitut, bi lahko imeli za temelj inštitutske zbirke gramofonskih plošč. Vendar inštitut zbirke gramofonskih plošč še nekaj let ni imel, prav tako ni ohranjene dokumentacije, ki bi podrobneje pojasnila, kdaj in kako so posamezne plošče prišle na inštitut. Plošče tudi niso datirane, kar je sicer splošna težava pri starejših gramofonskih ploščah. Šele v poročilih po končani 2. sv. vojni se nenadoma začne pojavljati podatek, da ima inštitut zbirko gramofonskih plošč. Spomladi leta 1945, torej takoj po osvoboditvi, je obsegala zbirka 50 plošč, konec leta pa že 59; poznejša poročila navajajo še višje številke (do največ 83). Kljub nekaterim konkretnim načrtom za nadaljnja snemanja, ki se omenjajo $\mathrm{v}$ arhivskih poročilih in dokumentih iz tega obdobja, ni podrobnejših podatkov, da bi se le-ta resnično izvedla. Tako ni ohranjene arhivske 
dokumentacije, ki bi pojasnila, kdaj in kako so posnetki nastali ter kdaj jih je inštitut vključil v svojo gramofonsko zbirko.

Danes šteje zbirka 69 obojestranskih gramofonskih plošč; od tega je na 55 ploščah posneto slovensko gradivo, na ostalih 14 ploščah pa tuje, predvsem priredbe ruskih in ukrajinskih ljudskih pesmi. $V$ veliki večini so v zbirki plošče posebne vrste, ki so bile izdelane s postopkom neposrednega rezanja (snemanja). Gre za unikatne plošče, ki pogosto obstajajo le v enem izvodu, kar daje posnetkom posebno dokumentarno vrednost. Na njih so posnete različne izvedbe ljudskih pesmi, pogosto v priredbi Franceta Marolta in v izvedbi »Maroltovega « Akademskega pevskega zbora pod njegovim umetniškim vodstvom. Tako ohranjeni posnetki in arhivska dokumentacija ne razkrivajo le Maroltovih prizadevanj za pridobitev snemalne naprave in načrtovanje njene uporabe za raziskovalno, izobraževalno in umetniško delo, temveč tudi njegov pogled na ljudsko glasbo in razumevanje »avtentične« podobe ljudske pesmi v njegovem času.

\section{ABOUT THE AUTHOR}

DRAGO KUNEJ (drago.kunej@zrc-sazu.si) is a senior research fellow at the Institute of Ethnomusicology of the Research Centre of the Slovenian Academy of Sciences and Arts, and the head of its Sound Archives. He is assistant professor at the Academy of Music and at the Faculty of Arts, University of Ljubljana, where his area of teaching focuses on ethnomusicology and musical acoustics. He is actively involved in the technical and methodological aspects of sound recording for research purposes and the problems of sound preservation, restoration, re-recording, digitization, and archiving. He researches the history of sound recordings and early ethnomusicological sound documents in Slovenia, recordings as a source for ethnomusicology research, traditional musical instruments, folk dance ensembles and migrant music.

\section{O AVTORJU}

DRAGO KUNEJ (drago.kunej@zrc-sazu.si), višji znanstveni sodelavec na Glasbenonarodopisnem inštitutu Znanstvenoraziskovalnega centra Slovenske akademije znanosti in umetnosti, je vodja inštitutskega Zvočnega arhiva, na Akademiji za glasbo in Filozofski fakulteti Univerze v Ljubljani pa predavatelj za področje etnomuzikologije in glasbene akustike. Preučuje tehnične in metodološke postopke zvočnega snemanja za raziskovalne namene in se ukvarja s problematiko zaščite, restavriranja, presnemavanja, digitaliziranja in arhiviranja zvočnega gradiva. Raziskuje zgodovino zvočnih snemanj in prve etnomuzikološke zvočne posnetke (s poudarkom na slovenskem gradivu), uporabnost zvočnih dokumentov za etnomuzikološke raziskave, ljudska glasbila, delovanje folklornih skupin in glasbo izseljencev. 